\title{
CHANGES IN mRNA LEVELS OF INTRACELLULAR FATTY ACID METABOLISM REGULATORS IN HUMAN HEPATOMA HepG2 CELLS FOLLOWING THEIR TREATMENT WITH NON-ESTERIFIED FATTY ACIDS AND DEHYDROEPIANDROSTERONE
}

\author{
Miroslav Rypka*, Kateřina Červenková, Lenka Uherková, Hana Poczatková, Kateřina \\ Bogdanová, Jaroslav Veselý
}

\begin{abstract}
Department of Pathological Physiology, Faculty of Medicine, Palacký University, 77515 Olomouc, Czech Republic E-mail:mirek@tunw.upol.cz
\end{abstract}

Received: October 3, 2005; Accepted (with revisions): November 14, 2005

Key words: Fatty acids/Protein kinase C (PKC)/Liver fatty acid binding protein (L-FABP)/Insulin resistance/HepG2 cells

The effects of non-esterified fatty acids (NEFA) and hormone dehydroepiandrosterone (DHEA) on the levels of mRNAs of protein kinase $C(P K C)-\delta$ and $-\varepsilon$ isoforms and those of liver fatty acid binding protein (L-FABP) were investigated in the human hepatoma HepG2 cell line. The cells were kept in low-serum, low-albumin medium during experiments. Low FA levels $(100 \mu \mathrm{M})$ and time intervals of $4 \mathrm{~h}$ and $20 \mathrm{~h}$ were used. In these conditions, the saturated (palmitic, stearic) and monounsaturated (oleic) acids rather selectively stimulated PKC- $\varepsilon$ mRNA levels. Unexpectedly, we found that these acids also suppressed liver fatty-acid binding protein (L-FABP) mRNA levels. DHEA in pharmacological doses $(100 \mu \mathrm{M})$ produced a significant increase in PKC- $\delta$ and $-\varepsilon$ mRNA levels. Although molecular mechanisms underlying the identified changes have not been investigated in this paper, our findings emphasize that NEFA-induced modulation of mRNA levels of key signalling components represent an additional mechanism for how the ambient NEFA can influence metabolic homeostasis in cells.

\section{INTRODUCTION}

The mechanisms by which ambient non-esterified fatty acids (NEFA) alter gene expression in cells are largely unknown. In fact, there are very different routes for FA to regulate a variety of genes (reviewed in ${ }^{1,2}$ ). Significantly, the protein kinase $\mathrm{C}$ (PKC) family of intracellular serine/threonine protein kinases that plays a prominent role in a number of signalling pathways regulating cell metabolism, growth, and death has been implicated in mediating FA-induced modulation of gene expression (reviewed $\left.\mathrm{in}^{3-6}\right)$. For instance, some members of the novel (n-) group of PKC isoenzymes that do not require $\mathrm{Ca}^{2+}$ but are sensitive to diacylglycerol (DAG) and to artificial PKC activators phorbol esters, have been reported to influence several genes including, for example, the LDL receptor gene, whose control is considered as the major mechanism by which dietary and hormonal factors control plasma lipid and cholesterol levels. ${ }^{7-11}$ Furthermore, PKCs have been implicated in mediating insulin action in a number of cell types and may contribute to the development of insulin resistance in tissues, including liver (reviewed in, e.g., ${ }^{3,4}$ ). Available data remain controversial indicating the existence of many gaps in our concepts of how PKCs function, however. In particular, liver cells have attracted less attention and are studied less extensively compared with adipocytes and skeletal muscles and while some have reported activation of PKC isoforms in hepato- cytes or hepatoma cell lines, ${ }^{12-16}$ others have failed to obtain evidence of PKC activation in liver cells after insulin stimulation. ${ }^{17,18}$ Nevertheless, there seems to be a general consensus that abundance and excessive availability of plasma NEFA in obese individuals may lead to insulin resistance attempting to prevent accumulation of these energy substrates that may cause cell overload, lipotoxicity, or "lipid trauma" featuring metabolic syndrome..$^{19,20}$ Indeed, more than a decade ago it has been suggested to view insulin resistance not solely as a disease of glucose homeostasis but, at least equally, as a lipid metabolism defect. ${ }^{21}$ Due to its anatomical location, the liver, supplied by blood through the portal vein is easily exposed to NEFA overflow released from visceral fat. Activation of PKC isoenzymes by ambient FA has been evidenced previously ${ }^{22}$ and interpreted as a result of the combined action of elevated intracellular long-chain acyl CoA (LCAC) derivatives that can give rise to diacylglycerol (DAG), a known potent activator of PKCs, accumulation of $\mathrm{Ca}^{2+}$, and/or of NEFA themselves. ${ }^{22-24}$ Using lipid infusions in rats in vivo, Lam et al. ${ }^{25}$ have identified the $n-P K C-\delta$ isoform as a potential important player in sustained insulin resistance induced by NEFA in this organ. At variance with this finding, Samuel et al. ${ }^{26}$ have demonstrated abundance of the n-PKC- $\varepsilon$ isoform, but not the PKC- $\delta$ isoform, in liver cell membranes from high-fat fed animals. Recent studies have also indicated that in obese subjects with type 2 diabetes, the activity of various PKC isoforms is higher than in controls. ${ }^{27,28}$ 
In contrast to FA, several studies suggest that hormone dehydroepiandrosterone (DHEA), a $\mathrm{C}_{19}$ steroid (3ß-hydroxy-5-androsten-17-one), and its sulfoconjugated derivative (DHEA-S) that are major secretory products of the human adrenal cortex ${ }^{29}$ can protect against many ageassociated diseases, including diabetes. ${ }^{30-32}$ Reportedly, DHEA stimulates insulin sensitivity in rat adipocytes, which has been attributed to activation of PKCs, phosphatidylinositol-3-kinase, and/or phospholipase D. ${ }^{33,34}$ DHEA has also been found to increase mRNA levels of peroxisome proliferator-activated receptors (PPARs) in adipocytes. Some of these effects can be mediated by one or more nuclear transcription factors. ${ }^{35}$

An important position of small ( $15 \mathrm{kDa})$ cytosolic, specific fatty-acid binding proteins (FABPs) that represent intracellular fatty acid carrier equivalents to plasma albumin has been evaluated recently (reviewed in $^{36}$ ). In particular, the L-FABP isoform is expressed in liver and at lower concentrations, also in kidney and intestine epithelium. The primary function of FABPs is to target fatty acids to their destinies in the cytoplasm and/or to nuclei in cells. Other functions of FABPs include protection of cells against the unfavourable effects of fatty acids. The expression of FABP is regulated primarily at the transcriptional level by a mechanism involving PPARs. Fatty acids can influence a variety of genes through their interaction with FABPs and, in turn, also modulate expression of FABP genes themselves. ${ }^{37-41}$

During this pilot study, we utilized human hepatoma HepG2 cells that had been previously shown to be a reliable experimental model exhibiting lipoprotein metabolism, insulin sensitivity, responsiveness, and a multitude of lipid- and insulin-mediated effects. ${ }^{10,42}$ We focused on studying the mRNA level expression of PKC components of signalling cascades and FA-transporting machinery and questioned whether ambient NEFA would influence their mRNA levels in these cells when applied in low concentrations and prolonged time intervals (4 and $20 \mathrm{~h}$ ). Furthermore, we attempted to evaluate effects of DHEA on the same components. We obtained data showing that NEFA were able to moderately up-regulate PKC- $\varepsilon$ and $-\delta$ mRNA levels and, surprisingly, reduce L-FABP mRNA levels in HepG2 cells.

\section{MATERIALS AND METHODS}

Materials. HepG2 cells were obtained from ATCC (Rockville, MD, USA). The Protease Inhibitor Cocktail was from Roche Diagnostics (Mannheim, Germany). Dehydroepiandrosterone (DHEA), Eagle's mimimum essential medium (EMEM), fetal bovine serum (FBS), penicillin, streptomycin, trypsin, the Phosphatase Inhibitor Cocktail 1, bovine serum albumin (BSA), fatty acid-free BSA, fatty acids (FA), phorbol myristate acetate (PMA), and all other chemicals were purchased from SigmaAldrich (St. Louis, MO, USA).
Preparation of the FA-BSA complex. FA-free BSA was dissolved in EMEM medium supplemented with 1\% FBS and individual FA were added to this solution to achieve 2:1 FA/BSA ratios. The mixtures were vortexed and sonicated until optically clear and used immediately.

The cell culture. HepG 2 cells were cultured in $75 \mathrm{~cm}^{2}$ flasks with EMEM supplemented with $10 \%$ FBS, $1 \mathrm{mM}$ sodium pyruvate, $2 \mathrm{mM}$ L-glutamine, and $50 \mathrm{IU} / \mathrm{ml}$ penicillin/streptomycin. The medium was refreshed every 2-3 days. The cells were maintained in a humidified $5 \%$ $\mathrm{CO}_{2}$ and $95 \%$ air atmosphere at $37{ }^{\circ} \mathrm{C}$ to grow to about $80 \%$ confluence. The medium was then aspirated, the cells were washed twice with ice-cold phosphate buffered saline (PBS; 0.1 M phosphate buffer, $\mathrm{pH} 7.4,0.9 \% \mathrm{NaCl}$ ), and switched to the same EMEM medium supplemented with $1 \%$ FBS and FA-BSA complexes added each to the final concentrations of $100 \mu \mathrm{M}$ FA. The final concentration of BSA was adjusted to $1 \%$ in all samples. The cells were then further incubated for $4 \mathrm{~h}$ or 20 hours before being fractionated and assayed. The same $1 \%$ FBS, $1 \%$ BSA medium without FA was used to incubate control cells. Incubation with $0.1 \mu \mathrm{M}$ PMA, a known PKC activator, in the medium was used as another control. In parallel incubations, DHEA was present at $1 \mu \mathrm{M}$ and $100 \mu \mathrm{M}$ concentrations. The data represent means of two separate analyses.

Quantitative mRNA analysis. Levels of mRNA were measured by a real-time PCR following reverse transcription (RT). Total RNA was isolated from about $80 \%$ confluent cell monolayers $\left(10^{6}\right.$ cells $)$ using High Pure RNA Isolation kit and mRNA reversely transcribed using Transcriptor First Strand cDNA Synthesis kit (Roche Diagnostics, Mannheim, Germany). Aliquots of the reversely transcribed samples were used for the LightCycler System using the FastStart DNA MasterPLUS SYBR Green I kit (Roche). Primer sequences were adopted from data of Berdiev et al. ${ }^{43}$ (PKC- $\delta$, PKC- $\varepsilon$ ), Blanquart et al. ${ }^{44}$ (cyclophilin A), Kemp et al. ${ }^{45}$ (glyceraldehyde-3-phosphate dehydrogenase; GAPDH), and Sumida et al. ${ }^{46}$ ( $\beta$-actin) or designed by us (L-FABP; 5'-GTGTCGGAAATCGTGC-3' and 5'-GATTATGTCGCCGTTGAG-3' are the forward and reverse primers, respectively) using LightCycler Probe Design software package (Roche) from gene sequences obtained from National Center for Biotechnology Information (NCBI) nucleotide database and synthesized by Metabion International (Martinsried, Germany).To compensate for variations in input RNA amounts, the mRNA values in each sample were normalized for an appropriate housekeeping gene (GAPDH, cyclophilin A, and $\beta$-actin for FA, and GAPDH and cyclophilin A for PMA). Controls without RT and with no cDNA template were tested in parallel with each assay and all samples were run in duplicate. The quality of RT-PCR products were further confirmed by melting curve analysis and by agarose gel electrophoresis of amplification products using visualization with ChemiGenius System (Syngene). 

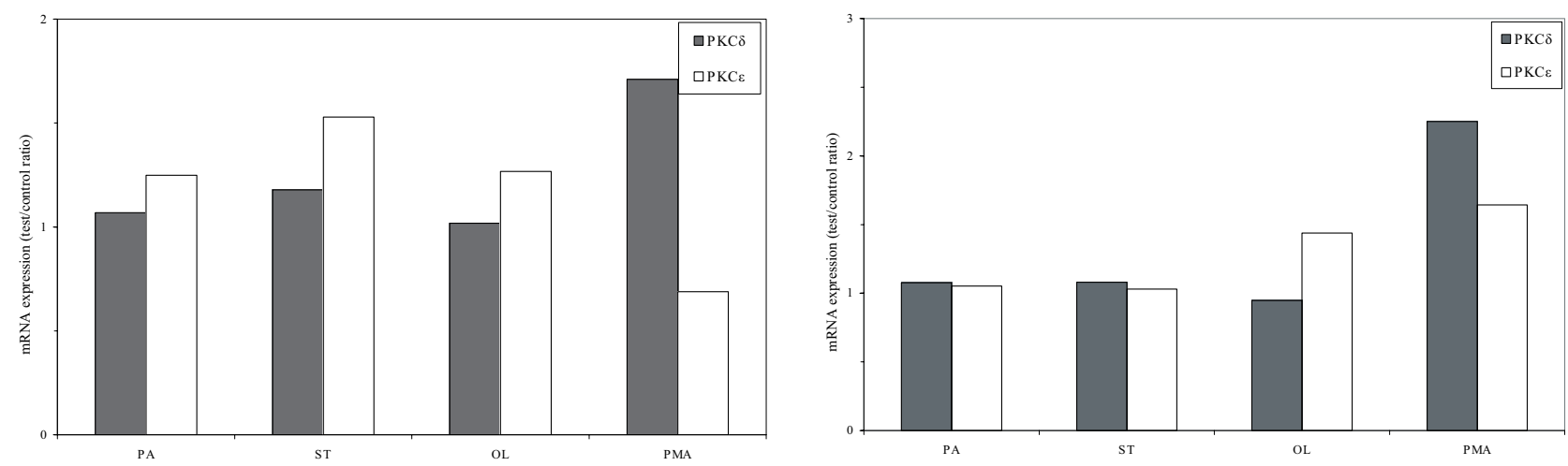

Fig. 1. Effects of saturated and monounsaturated fatty acids and PMA on the PKC- $\delta$ and $-\varepsilon$ mRNA levels in HepG2 cells. (left), $4 \mathrm{~h}$ incubation period. (right), $20 \mathrm{~h}$ incubation period. PA, palmitic acid, ST, stearic acid, OL, oleic acid. Data represent means of two separate analyses.

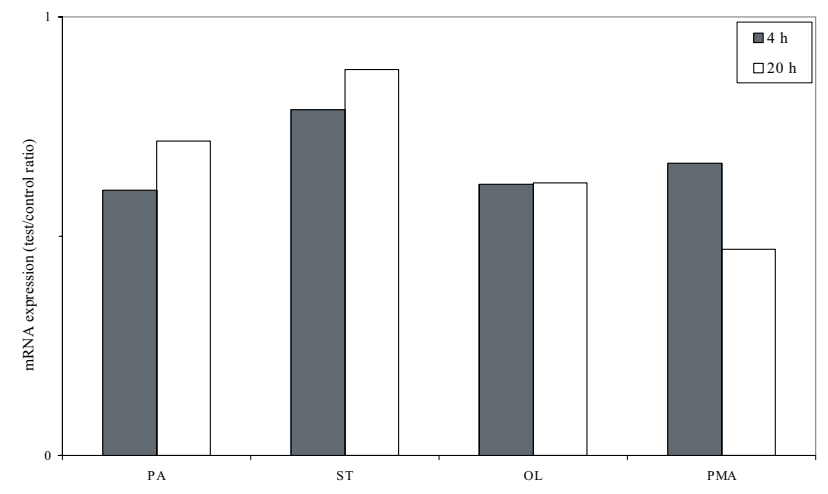

Fig. 2. Effects of $4 \mathrm{~h}$ and $20 \mathrm{~h}$ treatment by saturated and monounsaturated fatty acids and PMA on the LFABP mRNA levels in HepG2 cells. PA, palmitic acid, ST, stearic acid, OL, oleic acid. Data represent means of two separate analyses.

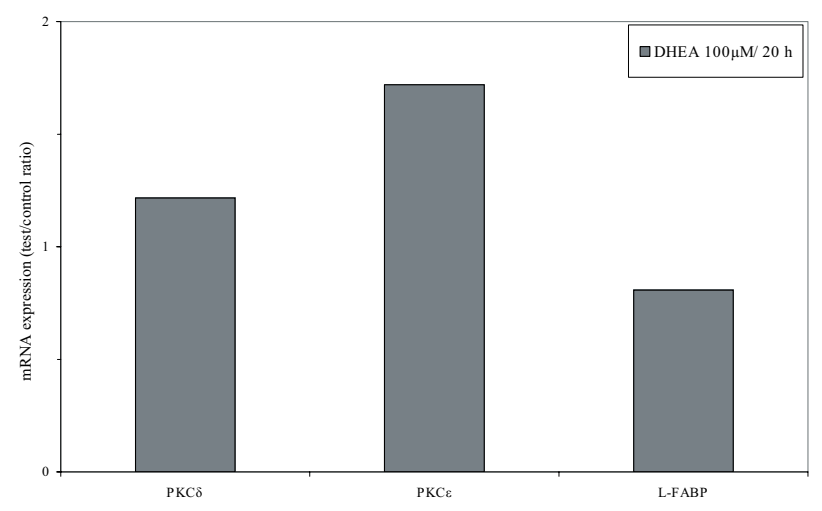

Fig. 3. Effects of $20 \mathrm{~h}$ treatment by $100 \mu \mathrm{M}$ DHEA on the PKC- $\delta,-\varepsilon$ and L-FABP mRNA levels in HepG2 cells. Data represent means of two separate analyses.

\section{RESULTS}

HepG 2 cells were incubated in the presence of palmitic, stearic, and oleic acids to evaluate whether the mRNA levels of intracellular FA metabolism regulators is influenced by ambient NEFA applied in low concentrations. After the incubation for $4 \mathrm{~h}$ and $20 \mathrm{~h}$ periods, quantitative real-time PCR was used to examine NEFA effects on PKC $-\delta$ and $-\varepsilon$ mRNAs. In Figure 1 it can be seen that the saturated and monounsaturated acids modestly but rather selectively increased PKC- $\varepsilon$ mRNA over the $4 \mathrm{~h}$ and/or $20 \mathrm{~h}$ incubation periods. The most potent stimulator was stearic acid that also slightly increased PKC- $\delta$ mRNA. The effect of oleic acid on PKC- $\varepsilon$ mRNA was enhanced after $20 \mathrm{~h}$ while that of palmitic and stearic acids was no longer evident over the $20 \mathrm{~h}$ incubation period (Fig $1 \mathrm{~b}$ ). In comparison, artificial PKC activator PMA reduced $(4 \mathrm{~h})$ and then increased PKC- $\varepsilon$ mRNA, and robustly increased PKC- $\delta$ mRNA levels over time (Fig 1a,b).

The mechanisms by which FA enter cells employ a variety of proteins. ${ }^{1,2}$ To address the question of whether FA can influence, at the mRNA level, metabolism of the proteins that mediate plasma membrane transport and target FA to different cytoplasmatic destinations the effects of NEFA on mRNA expression of small cytosolic L-FABP protein that is known to play a crucial role in FA cytoplasmatic trafficking were re-examined. Surprisingly, we found that palmitic, stearic, and oleic acids considerably reduced L-FABP mRNA levels in our model (Fig. 2). Additionally, PMA also reduced the mRNA level of this protein markedly (Fig. 2).

Protective action of DHEA against the adverse effects of NEFA has been reported repeatedly. Attempting to extend the knowledge of DHEA influence on its potential cytoplasmatic targets, we examined the effects of physiological and supraphysiological concentrations ( $1 \mu \mathrm{M}$ and $100 \mu \mathrm{M}$, respectively) on the abundance of PKC and L-FABP mRNAs in HepG2 cells. We found that the prolonged $(20 \mathrm{~h})$ treatment with $100 \mu \mathrm{M}$ DHEA concentrations increased PKC- $\delta$ mRNA and that of PKC- $\varepsilon$, in particular, while not changing L-FABP mRNA considerably (Fig. 3). 


\section{DISCUSSION}

Previous studies have lent credence to the idea that PKCs, in addition to their role as physiological mediators of some of insulin effects, may be at least partially responsible for the development of insulin resistance. Previous authors have also reported that PKCs can be activated by ambient FA, both in vitro and in vivo conditions and in obese individuals (reviewed in ${ }^{23,24}$ ). Despite the well-described, acute effects of various agents on PKC activation occurring within minutes after the stimulation, it has been argued that FA-induced development of insulin resistance requires periods of hours, at least (reviewed in $^{20,47}$ ). Indeed, prolonged treatments lasting for hours to days have been used to demonstrate effects of growth regulators and/or elevated plasma lipids on PKC translocation and insulin resistance development in vivo. ${ }^{25,26}$ The long periods are assumed to be required to influence hepatic glucose production by impairing insulin control of gluconeogenesis and/or that of glycogenolysis, in particular, and to alter gene expression ${ }^{1,10,48}$ that can affect autoregulation in liver. ${ }^{20,23,47,49}$ From this it is obvious that the prolonged, $4 \mathrm{~h}$ and $20 \mathrm{~h}$ incubation intervals as used in this work have been more appropriate in detecting sustained metabolic and/or adverse effects of FA, rather than those that might appear very early, i.e., within minutes, in cells after their stimulation. Of note, about $20 \mathrm{~h}$ in vitro incubation periods have been also reported as optimal to evaluate down-regulation of PKCs through the exposure of cells to phorbol esters. ${ }^{48,50}$ However, it is clear from our experimental protocol that we did not address the question of whether the FA effects, observed by us, were direct or indirect ones. Potentially, some of the effects we observed could be those that persisted or were even delayed after the ambient FA had been consumed by the cells. In fact, the effects could be caused by FA themselves, by their metabolites (e.g., desaturation products, LCAC, DAG, lipoproteins, ceramides, products of FA oxidation, etc.), or by by-products of their metabolism, such as, e.g., reactive oxygen species. This important issue remains to be further explored.

Increase in mRNAs, which roughly coincide with at least partial down-regulation of their appropriate PKC protein isoforms following prolonged treatment of cells with insulin, have been reported by previous authors in non-liver cells. ${ }^{51,52}$ Those authors hypothesized that such insulin-induced, plasma membrane receptor-mediated increase in PKC mRNAs following the redistribution and depletion of PKC isoenzymes is a compensatory mechanism to maintain PKC levels in insulin-stimulated cells. Although the activation of PKC isoenzymes by ambient FA has been evidenced previously at the protein level ${ }^{22}$, we have shown here for the first time that long-term treatment by FA can also lead to modulation of PKC mRNA levels, at least in HepG2 cells. Collectively, from our findings it may be surmised that studies on PKC dependency of cellular effects of ambient NEFA may not be sufficient to interpret within the limits of the current experimental paradigm that is predominantly focused on the PKC-iso- form protein activation and/or translocation. Interestingly, as shown in figure 3, PKC mRNA levels have been also stimulated by prolonged $(20 \mathrm{~h})$ treatment with supraphysiological doses of DHEA.

While increasing PKC mRNAs, low ambient NEFA treatment yielded a decrease in mRNA of L-FABP in HepG 2 cells. The literature reveals, however, that this finding is at variance with the results of other authors who clearly demonstrated FA to act as potent inductors of L-FABP gene expression in rodents. ${ }^{38-41}$ We do not believe that the finding is an artefact although the data that support this are only indirect, for the present: first, the finding has been further substantiated by the concordant effect of PMA (Fig. 2) and, second, it was not observed in the presence of any of the six polyunsaturated FA examined by us (including linoleic, arachidonic, phytanic, docosahexanoic, and two conjugated linoleic acids; data not shown). We assume this disparity is most probably the result of interspecies differences or a specific feature of HepG 2 cells themselves. Alternatively, or additionally, the study design, composition of cultivation media and/or concentrations of FA should be considered as well. This problem deserves further attention. In this connection it is also relevant that FA entering hepatocytes are predominantly diverted to the re-esterification pathway, rather than oxidation, resulting in accumulation of DAG and triglycerides where they are stored before being secreted in VLDL, and/or to synthesis of ceramides (reviewed $\left.i^{23,24}\right)$. L-FABP has been reported decreased in cells under conditions of limited oxidation of fatty acids. ${ }^{53}$ Thus, the decrease in L-FABP mRNA expression as observed by us is consistent with the idea that it may reflect an adaptive mechanism aiming at to protect the cells against FA overflow. This is supported indirectly by the fact that knockout mouse lacking L-FABP gene or liver cells with reduced L-FABP expression exhibited both a reduced rate of long chain FA uptake and their oxidation under conditions of lipid supply. ${ }^{41,54-56}$

Overall, although there are various mechanisms described in the literature as to how NEFA may contribute to lipotoxicity, the present data direct attention to changes in mRNA levels of important intracellular signalling cascade components that may contribute to NEFA effects. Further analysis is clearly needed to provide conclusive evidence for the physiological importance of mechanisms underlying these findings.

\section{ACKNOWLEDGEMENT}

This work was supported, in parts, by the Ministry of Education, Youth, and Sports, Czech Republic, Grants COST B17.20, COST B17.001, and MSM 6198959205. 


\section{REFERENCES}

1. Jump DB, Clarke SD (1999) Regulation of gene expression by dietary fat. Annu Rev Nutr 19, 63-90.

2. Duplus E, Forest C. (2002) Is there a single mechanism for fatty acid regulation of gene transcription? Biochem Pharmacol 64, 893-901.

3. Farese RV. (2002) Function and dysfunction of aPKC isoforms for glucose transport in insulin-sensitive and insulin-resistant states. Am J Physiol Endocrinol Metab 283, E1-E11.

4. Formisano P, Beguinot F. (2001) The role of protein kinase $\mathrm{C}$ isoforms in insulin action. J Endocrinol. Invest 24, 460-467.

5. Parker PJ, Murray-Rust J. (2004) PKC at a glance. J. Cell Sci. 117, 131-132.

6. Poczatková H, Rypka M, Riegrová D, Veselý J. (2005) Proteinkináza $\mathrm{C}(\mathrm{PKC})$ a její role v metabolismu mastných kyselin a glukózy. Čs. Fyziol. 54, 120-124.

7. Goldstein JL, Brown MS. (1990) Regulation of the mevalonate pathway. Nature 343, 425-430.

8. Kumar A, Chambers TC, Cloud-Heflin BA, Mehta KD. (1997) Phorbol ester-induced low density lipoprotein receptor gene extression in HepG2 cells involves protein kinase C-mediated p42/44 MAP kinase activation. J Lipid Res 38, 2240-2248.

9. Liu WS, Heckman CA. (1998) The sevenfold way of PKC regulation. Cell Signal 10, 529-542.

10. Mehta KD, Radominska-Pandya A, Kapoor GS, Dave B, Atkins BA. (2002) Critical role of diacylglycerol- and phospholipid-related protein kinase $\mathrm{C} \varepsilon$ in response to depletion of cholesterol. Mol Cell Biol 22, 3783-3793.

11. Wilson GM, Roberts EA, Deeley RG. (1997) Modulation of LDL receptor mRNA stability by phorbol esters in human liver cell culture models. J Lipid Res 38, 437-446.

12. Caruso M, Maitan MA, Bifulco G, Miele C, Vigliotta G, Oriente F, Formisano P, Beguinot F. (2001) Activation and mitochondrial translocation of protein kinase $\mathrm{C} \delta$ are necessary for insulin stimulation of pyruvate dehydrogenase complex activity in muscle and liver cells. J Biol Chem 276, 45088-45097.

13. Cooper DR, Hernandez H, Kuo JY, Farese RV. (1990) Insulin increases the synthesis of phospholipid and diacylglycerol and protein kinase $\mathrm{C}$ activity in rat hepatocytes. Arch Biochem Biophys 276, 486-494

14. Fiory F, Oriente F, Miele C, Romano C, Trencia A, Alberobello AT, Esposito I, Valentino R, Beguinot F, Formisano P. (2004) Protein kinase $\mathrm{C}-\zeta$ and protein kinase $\mathrm{B}$ regulate distinct steps of insulin endocytosis and intracellular sorting. J Biol Chem 279 11137-11145.

15. Messina JL, Weinstock RS. (1994) Evidence for diverse roles of protein kinase- $\mathrm{C}$ in the inhibition of gene expression by insulin the tyrosine aminotransferase, albumin, and phosphoenolpyruvate carboxykinase genes. Endocrinology 135, 2327-2334.

16. Nivet V, Clot JP, Do XT, Barrault V, Prelot M, Durant D. (1993) Evidence that growth hormone stimulates protein kinase $\mathrm{C}$ activity in isolated rat hepatocytes. Metabolism 42, 1291-1295.

17. Probst I, Beuers U, Drabent B, Unthan-Fechner K, Bütikofer P. (2003) The diacylglycerol and protein kinase C pathways are not involved in insulin signalling in primary hepatocytes. Eur J Biochem 270, 4635-4646.

18. Vaartjes WJ, de Haas CGM, van den Bergh SG. (1986) Phorbol esters, but not epidermal growth factor or insulin, rapidly decrease soluble protein kinase $\mathrm{C}$ activity in rat hepatocytes. Bichem Biophys Res Commun 138, 1328-1333.

19. Unger RH. (2003) Lipid overload and overflow: metabolic trauma and the metabolic syndrome. Trends Endocrinol Metabol 14 398-403.

20. Boden G . (2002) Interaction between free fatty acids and glucose metabolism. Curr Opin Clin Nutr Metab Care 5, 545-549.

21. McGarry JD. (1992) What if Minkowski had been ageusic? An alternative angle on diabetes. Science $258,766-770$.

22. Díaz-Guerra MJ, Junco M, Bosca L. (1991) Oleic acid promotes changes in the subcellular distribution of protein kinase $\mathrm{C}$ in isolated hepatocytes. J Biol Chem 266, 23568-23576.
23. Lam TKT, Carpentier A, Lewis GF, van der Werve G, Fantus IG, Giacca A. (2003) Mechanisms of the free fatty acid-induced increase in hepatic glucose production. Am J Physiol Endocrinol Metab 284, E863-E873.

24. Lewis GF, Carpentier A, Adeli K, Giacca A. (2002) Disordered fat storage and mobilization in the pathogenesis of insulin resistance and type 2 diabetes. Endocrin Rev 23, 201-229.

25. Lam TKT, Yoshii H, Haber CA, Bogdanovic E, Lam L, Fantus IG, Giacca A. (2002) Free fatty acid-induced hepatic insulin resistance: a potential role for protein kinase C- $\delta$. Am J Physiol Endocrinol Metab 283, E682-E691.

26. Samuel VT, Liu ZX, Qu X, Elder BD, Bilz S, Befroy D, Romanelli AJ, Shulman GI. (2004) Mechanism of hepatic insulin resistance in non-alcoholic fatty liver disease. J Biol Chem 279, 32345-32353.

27. Considine RV, Nyce MR, Alle LE, Morales LM, Triester S, Serrano J, Colberg J, Lanza-Jacoby S, Caro JF. (1995) Protein kinase C is increased in the liver of humans and rats with non-insulin-dependent diabetes mellitus: an alteration not due to hyperglycemia. J Clin Invest 95, 2938-2944.

28. Qu X, Seale JP, Donnelly R. (1999) Tissue and isoform-selective activation of protein kinase $\mathrm{C}$ in insulin-resistant obese Zucker rats: effects of feeding. J Endocrinol 162, 207-214.

29. Svačina S, Kvapil M, Haas T, Wichterle D, Bendlová B, Štolba P, Šonka J. (1997) Dehydroepiandrosterone-insulin relationship in minimal model based IVGTT analysis Diabetologia 40(Suppl. 1), $1156-1156$

30. Coleman DL, Leiter EH, Schwizer RW. (1982) Therapeutic effects of dehydroepiandrosterone (DHEA) in diabetic mice. Diabetes 31 , 830-833.

31. Coleman DL, Schwizer RW, Leiter EH. (1984) Effect of genetic background on the therapeutic effects of dehydroepiandrosterone (DHEA) in diabetes-obesity mutants and in aged normal mice. Diabetes 33, 26-32.

32. Aoki K, Nakajima A, Mukasa K, Osawa E, Mori Y, Sekihara H (2003) Prevention of diabetes, hepatic injury, and colon cancer with dehydroepiandrosterone. J Steroid Biochem Mol Biol 85, 469-472.

33. Ishizawa M, Ishizuka T, Kajita K, Miura A, Kanoh Y, Kimura M, Yasuda K. (2001) Dehydroepiandrosterone (DHEA) stimulates glucose uptake in rat adipocytes: activation of phospholipase D. Comp Biochem Physiol B Biochem Mol Biol 130, 359-364.

34. Ishizuka T, Kajita K, Miura A, Ishizawa M, Kanoh Y, Itaya S, Kimura M, Muto N, Mune T, Morita H, Yasuda K. (1999) DHEA improves glucose uptake via activations of protein kinase $\mathrm{C}$ and phosphatidylinositol 3-kinase. Am. J. Physiol. Endocrinol Metab 276, E196-E204.

35. Kochan Z, Karbowska J. (2004) Dehydroepiandrosterone up-regulates resistin gene expression in white adipose tissue. Mol Cell Endocrinol 218, 57-64.

36. Pelsers MMAL, Hermens WT, Glatz JFC. (2005) Fatty acid-binding proteins as plasma markers of tissue injury. Clin Chim Acta 352, 15-35.

37. Gilde A, Van Bilsen M. (2003) Peroxisome proliferator-activated receptors (PPARs): regulators of gene expression in heart and skeletal muscle. Acta Physiol Scand 178, 425-434.

38. Meunier-Durmort C, Poirier H, Niot I, Forest C, Besnard P. (1996) Upregulation of gene expression of the gene for liver fatty acid-binding protein by long-chain fatty acids. Biochem J 319, 483-487.

39. Poirier H, Niot I, Monnot MC, Braissant O, Meunier-Durmort C, Costet P, Pineau T, Wahli W, Wilson TM, Bernad P. (2001) Differential involvement of peroxisome-proliferator-activated receptors alpha and delta in fibrate and fatty-acid-mediated inductions of the gene encoding liver fatty-acid-binding protein in the liver and the small intestine. Biochem J 355, 481-488.

40. Wolfrum C, Borrmann CM, Börchers T, Spener F. (2000) Fatty acids and hypolipidemic drugs regulate peroxisome proliferatoractivated receptors $\alpha$ - and $\gamma$-mediated gene expression via liver fatty acid binding protein: A signaling path to the nukleus. Proc. Nat. Acad. Sci. USA 98, 2323-2328.

41. Wolfrum C, Buhlmann C, Rolf B, Börchers T, and Spener F. (1999) Variation of liver-type fatty acid binding protein content in the 
human hepatoma cell line HepG2 by peroxisome proliferators and antisense RNA affects the rate of fatty acid uptake. Biochim Biophys Acta 1437, 194-201.

42. Nakajima K, Yamauchi K, Shigematsu S, Ikeo S, Komatsu M, Aizawa T, Hashizume K. 2000 Selective Attenuation of Metabolic Branch of Insulin Receptor Down-signaling by High Glucose in a Hepatoma Cell Line, HepG2 Cells. J Biol Chem 275, 2088020886.

43. Berdiev BK, Xia J, Jovov B, Markert JM, Mapstone TB, Gillespie GY, Fuller CM, Bubien JK, Benos DJ. (2002) Protein kinase C isoform antagonism controls BNaC2 (ASIC1) function. J Biol Chem 277, 45734-40.

44. Blanquart C, Mansouri R, Paumelle R, Fruchart JC, Staels B, Glineur C. (2004) The protein kinase $C$ signalling pathway regulates a molecular switch between transactivation and transrepression activity of the Peroxisome Proliferator-Activated Receptor alpha (PPAR $\alpha$ ). Mol Endocrinol 18, 1906-1918.

45. Kemp TJ, Causton HC, Clerk A. (2003) Changes in gene expression induced by $\mathrm{H}_{2} \mathrm{O}_{2}$ in cardiac myocytes. Biochem Biophys Res Commun 307, 416-421.

46. Sumida A, Fukuen S, Yamamoto I, Matsuda H, Naohara M, Azuma J. (2000) Quantitative analysis of constitutive and inducible CYPs mRNA expression in the HepG2 cell line using reverse transcription-competitive PCR.. Biochem Biophys Res Commun 267, 756-760.

47. Boden G. (2003) Effects of free fatty acids (NEFA) on glucose metabolism: Significance for insulin resistance and type 2 diabetes. Exp Clin Endocrinol Diabetes 111, 121-124.

48. Standaert ML, Avignon A, Arnold T, Saba-Siddique SI, Cooper DR, Watson J, Zhou X, Galloway L, Farese RV. (1996) Insulin translocates $\mathrm{PKC}-\varepsilon$ and phorbol esters induce and persistently translocate PKC- $\beta_{2}$ in BC3H-1 myocytes. Cell Signal 8, 313-316.
49. Boden G, Shulman GI. (2002) Free fatty acids in obesity and type 2 diabetes: defining their roel in the development of insulin resistance and $\beta$-cell dysfunction. Eur J Clin Invest 32, 14-23.

50. Maloney JA, Tsygankova O, Szot A, Yang L, Li Q, Williamson JR. (1998) Differential translocation of protein kinase C isozymes by phorbol esters, EGF, and ANG II in rat liver WB cells. Am J Physiol Cell Physiol 274, C974-C982.

51. Avignon A, Standaert ML, Yamada K, Mischak H, Spencer B., Farese RV. (1995) Insulin increases mRNA levels of protein kinase $\mathrm{C}-\alpha$ and $-\beta$ in rat adipocytes and protein kinase $\mathrm{C}-\alpha,-\beta$, and $-\theta$ in rat skeletal muscle. Biochem J 308, 181-187.

52. Zhao L, Standaert ML, Cooper DR, Avignon A, Farese RV. (1994) Effects of insulin on protein kinase C (PKC) in HIRC-B cells: specific activation of $\mathrm{PKC} \varepsilon$ and its resistance to phorbol ester-induced down-regulation. Endocrinology 135, 2504-2510.

53. Memon RA, Bass NM, Moser AH, Fuller J, Appel R, Grunfeld C, Feingold KR. (1999) Down-regulation of liver and heart specific fatty acid binding proteins by endotoxin and cytokines in vivo. Biochim Biophys Acta 1440, 118-126.

54. Erol E, Kumar, LS, Cline GW, Shulman GI., Kelly DP, Binas B. (2004) Liver fatty acid-binding protein is required for high rates of hepatic fatty acid oxidation but not for the action of PPAR- $\alpha$ in fasting mice. FASEB J 18, 347-349.

55. Martin GG, Danneberg H, Kumar LS., Atshaves BP., Erol E, Bader M, Schroeder F, Binas B. (2003) Decreased Liver Fatty Acid Binding Capacity and Altered Liver Lipid Distribution in Mice Lacking the Liver Fatty Acid-binding Protein Gene. J Biol Chem 278, 21429-21438.

56. Newberry EP, Xie Y, Kennedy S, Han X, Buhman KK, Luo J, Gross RW, Davidson NO. (2003) Decreased Hepatic Triglyceride Accumulation and Altered Fatty Acid Uptake in Mice with Deletion of the Liver Fatty Acid-binding Protein Gene. J Biol Chem 278, 51664-51672. 